Metals and Ceramics Division

\title{
SURVEY OF CERAMIC MACHINING IN JAPAN
}

\author{
B. P. Bandyopadhyay \\ University of North Dakota \\ Department of Mechanical Engineering \\ Grand Forks, ND 58202 \\ and \\ P. J. Blau \\ Metals and Ceramics Division \\ Oak Ridge National Laboratory \\ Oak Ridge, TN 37831-6063
}

Date Published: July 1993

\author{
Prepared for the \\ U.S. Department of Energy \\ Assistant Secretary for Energy Efficiency and Renewable Energy \\ Office of Transportation Technologies \\ EE 5101000 \\ Prepared by the \\ OAK RIDGE NATIONAL LABORATORY \\ Oak Ridge, TN 37831-6285 \\ managed by \\ MARTIN MARIETTA ENERGY SYSTEMS, INC. \\ for the \\ U.S. DEPARTMENT OF ENERGY \\ under contract DE-AC05-85OR21400
}




\section{TABLE OF CONTENTS}

Executive Summary. ...................... 1

1.0 Ceramics Machining Research and Development Organizations. ...... 2

1.1 Institute of Physical and Chemical Research (RIKEN)........ 2

1.2 Tokyo Institute of Technology. ................ 4

1.3 Isuzu Ceramics Research Institute. ............... 4

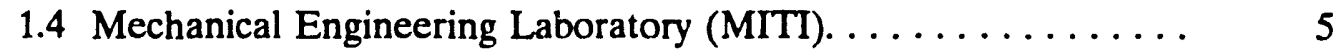

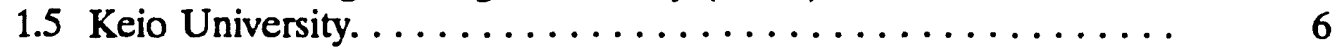

1.6 Institute of Vocational Training. ................ 6

1.7 Japan Fine Ceramics Center, Nagoya. ................ 8

1.8 Government Industrial Research Institute, Nagoya. . . . . . . . 12

1.9 Aichi Industrial Research Institute. . . . . . . . . . . . . 12

1.10 Chubu University. . . . . . . . . . . . . . . . . . 12

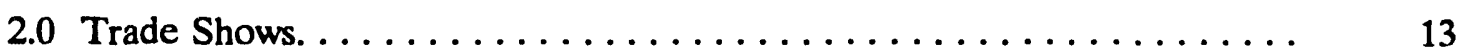

2.1 Nagaoya Ceramics Fair. ................... 13

2.2 Japan International Machine Tool Fair. ............. 14

3.0 Other Commercial Developments. .................. 15

3.1 New, Patented Bonding Process for Manufacturing

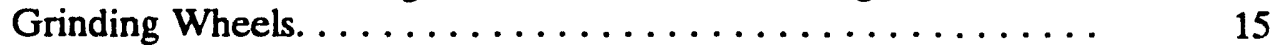

3.2 Ceramic Ball Valves. . . . . . . . . . . . . . . . . . 15

3.3 Tools To Withstand Contact with Molten Aluminum. ......... 15

3.4 Sintobrator, Ltd., Manufacturer of ELID Systems. . . . . . . . 16

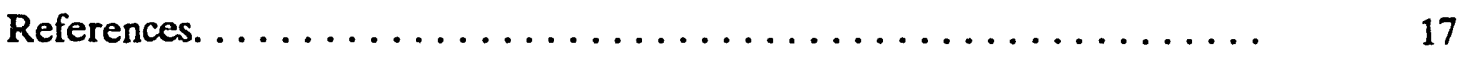

Appendix - Key Researchers in Ceramic Machining in Japan. . . . . . . . . 19 


\section{EXECUTTVE SUMMARY}

This report is a compilation of four subcontract reports provided by B. P. Bandyopadhyay who, while a visiting professor at Toyohashi University in Japan, conducted a survey of ceramic machining technology in that country from January 1 through December 31, 1992. Various aspects of machining technology were surveyed: types of parts being produced, types of ceramic materials being used, the nature of current ceramic machining research and development, and types of machine tools. The four separate reports compiled here were originally provided in a narrative, chronological form, and some of the information has been reorganized into topical areas for this compilation. This report is organized into three sections: The first describes ten ceramic machining research and development organizations and provides a reference list of their current technical publications; the second, two major trade shows; and the third, several other products and commercial developments noted during the course of Bandyopadhyay's stay in Japan. An Appendix lists key individuals who are currently conducting ceramic machining research in Japan. 


\subsection{CERAMICS MACH'NING RESEARCH AND DEVELOPMENT ORGANIZATIONS*}

The following ten orylanizations were visited during this survey:

\subsection{Institute of Physical and Chemical Research (RIKEN)}

The Institute of Phys cal and Chemical Research is also known as RIKEN. Established in 1917, RIKEN is a nonprofit ir stitute supported by the government's Science and Technology Agency. The institute is a research complex consisting of about fifty laboratories of various disciplines. Research is conducted under active collaborations with universities, other research institutions, and industries.

The Materials Fabrication Laboratory at RIKEN, headed by Takeo Nakagawa, has done significant research for the processing of fine ceramics. The Cast Iron Fiber Bonded Diamond Grinding Wheel (CIFF-D) developed by this institute for creep feed grinding of ceramics is now commercially available. The manufacturer's name is Sintobrator, Ltd. A heavy material removal rate (MRR), with good surface finish, has been reported with this type of a grinding wheel [1]:

$$
\begin{aligned}
& M R R=6600 \mathrm{~mm}^{3} / \mathrm{min} \text { and } \\
& R \max =0.1 \text { to } 2 \mu \mathrm{m} .
\end{aligned}
$$

A new complex grinding method named Ultrasonic Electrodischarging Grinding (US-ED-G) has also been developed at this institute. This method reduces the grinding force drastically. Therefore, US-ED-G will be helpful for grinding hard-to-grind ceramic materials that may appear in the future (e.g., $\left.\mathrm{TiB}_{2}\right)$ [2].

Continued research in ceramic grinding has revealed that, though the CIFB-D wheel is sufficiently strong, it is not suitable for continuous use. This is due to the difficulty in chip removal and absence of self-dressing. This will lead to unstable grinding qualities. RIKEN has been successful in developing a new grinding technique that will address the self-dressing problem. This technology, capable of producing a mirror surface finish on various materials when they are ground even in conventional grinding machines, uses Electrolytic In-Process Dressing (ELID) and fine grain CIFB-D wheels. Hitoshi Ohmori is the principal investigator of the ELID project in RIKEN.

The ELID grinding process consists of three stages:

1. precision trueing the grinding wheel,

2. pre-dressing process of the wheel by electrolysis, and

3. grinding process with electrolytic in-process dressing.

The ELID process is capable of producing parts six times faster than conventional grinding for a given surface quality. The method can be used to grind hard and brittle materials such as silicon wafers, glass, silicon nitride, silicon carbide, zirconium oxide, titanium alloys, special die steel, stainless

${ }^{*}$ Research sponsored by the U.S. Department of Energy, Assistant Secretary for Energy Efficiency and Renewable Energy, Office of Transportation Technologies, as part of the Ceramic Technology Project of the Materials Development Program, under contract DE-AC05-84OR21400 with Martin Marietta Energy Systems, Inc. 
steel, quartz, ferrites for magnetic heads, and tungsten carbide materials. The method is commercially available, and the ELID attachment can be purchased from a vendor. The ELID system's essential elements are metal bonded grinding wheel, electrolytic power source, and electrolytic coolant. The cost of an ELID system is around 1 million yen. Thirty companies in Japan are using this ELID technology. Toyota Motor has expressed interest in this technology for grinding of their cam shafts to a mirror finish (not made from ceramics). This is expected to significantly reduce the vibration in the car.

Several papers have been published in English by $\mathrm{H}$. Ohmori describing applications of his ELID method [3-5]. One recent paper on ELID grinding by Ohmori was presented at the Progress in Precision Engineering Conference held in Braunschweig, Germany, in May 1991 [5]. Ohmori was invited to the ISEM X conference to present his research. This conference was held in Magdeburg, Germany and his talk was on May 8, 1992. Some European companies are using Ohmori's ELID technique, one of which is in Munich, Germany (i.e., George Muller Nurnburg AG). Philips of the Netherlands has expressed interest in this technology also.

Applications of ceramic materials, ground by ELID technique, include:

1. $\mathrm{ZrO}_{2}$ for gage blocks produced by Mitutoyo;

2. tungsten-carbide in micrometers and for seals in engines;

3. silicon wafers for integrated circuits (ground to mirror surface in $2 \mathrm{~min}$ );

4. ferrites for magnetic heads;

5. tungsten-carbide dies for injection molding of compact discs;

6. Mo used for optical parts;

7. tungsten-carbide, silicon, and silicon-carbide (a mirror spherical surface for high-energy rays like $\mathrm{X}$ rays);

8. SiAJON [rolling mill (parts) produced by Hitachi for rolling aluminum]; and

9. sharp edge cutting tools from cubic boron nitride and diamond produced by Makino Seiki Company using ELID technology.

NACHI is a manufacturer of high precision grinding machines. The spindle of these machines is mounted on aerostatic bearings. By using ELID technology, a surface finish of Rmax in the order of $0.02 \mu \mathrm{m}$ can be produced.

Another area of research for machining ceramics at RIKEN is the development of a Vibrational Grinding System. The ceramic workpiece is provided with a low-frequency sine wave vibration (i.e., a frequency around $300 \mathrm{~Hz}$ or less than $1 \mathrm{kHz}$ ) and peak-to-peak amplitude of $15 \mu \mathrm{m}$ for hole grinding. The grinding wheel used was the CIFB-D wheel. $\mathrm{A1}_{2} \mathrm{O}_{3}$ and $\mathrm{Si}_{3} \mathrm{~N}_{4}$ were machined. Three advantages of the process are the following:

1. Grinding forces are reduced.

2. No chipping of the workpiece occurs, even at the corners.

3. It is cheaper than ultrasonic vibration systems.

The main disadvantage is the noisy operation.

Presently a workpiece of $100 \mathrm{~mm}$ diam can be accommodated on the vibrating table. Research is continuing on increasing the size of the vibrating table, which will allow machining of larger workpieces. Funding for the research is provided by private companies, totaling about 
10 million yen a year, which is used for the purchase of instrumentation. Grinding machines and tooling are donated by the companies. Salary and other expenses are supported by the government. NACHI sells the system.

\subsection{Tokyo Institute of Technology}

Some of the basic research on the production of ceramics is carried out at Tokyo Institute of Technology under the leadership of Yohtaro Matsuo. Studies were performed in several areas including:

1. The effect of additives on microstructure and mechanical properties of ceramics. The bases of these investigations were fracture mechanics and fracture statistics. Recently, micro mechanics has been used for the analysis.

2. The effect of Cyclic Cold Isostatic Pressing. This method is said to improve the structural reliability of sintered ceramics [6].

3. The effect of annealing on surface-machining damage. The major advantages are crack healing and reduction of residual stress [7].

Funds for the research are provided by both government and private companies. The government's contribution is about 6 to 10 million yen per year; the contribution from companies may be up to 2 million yen per year without any obligation to the companies.

\subsection{Isuzu Ceramics Research Institute}

The Isuzu Ceramics Research Institute is very similar to the High Temperature Materials Laboratory in Oak Ridge. Representatives of the institute stated from 1982 through 1985, silicon nitride ceramics with a bending strength of $750 \mathrm{MPa}$ were produced. Recently, a new method developed at the laboratory produced silicon nitride with a bending strength of over $1 \mathrm{GPa}$. The reasons for this improvement were said to be (1) high powder purity and (2) improvement of the sintering process (i.e., sintered at high gas pressure). The research institute also applies finite element methods to determine the bending strength, tensile strength, and fatigue strength, which enables them to determine the maximum stress level on specific parts. It has been stated that in Japan, a ceramic material with a fracture toughness $=11 \mathrm{MPa} \sqrt{ } \mathrm{m}$ has been developed.

A copy of a technical paper entitled "Studying of Grinding Process and Strength for Ceramic Heat Insulated Engine" was obtained [8]. This paper discusses the relationship between the grindingaffected layer, the strength, and the grinding parameters. It has been suggested that the affected layer be removed by precise grinding or lapping to improve the strength of the ceramic (see Fig. 1, reproduced from Fig. 18 of the paper).

According to the institute staff, an important area of research is the healing of cracks after grinding. There are three main ways in which the crack healing is accomplished:

1. in situ laser heating for crack healing,

2. chemical healing, and

3. heating.

Unfortunately, no further information on flaw healing was available during the visit. 
ORNL-DWG 93-10171

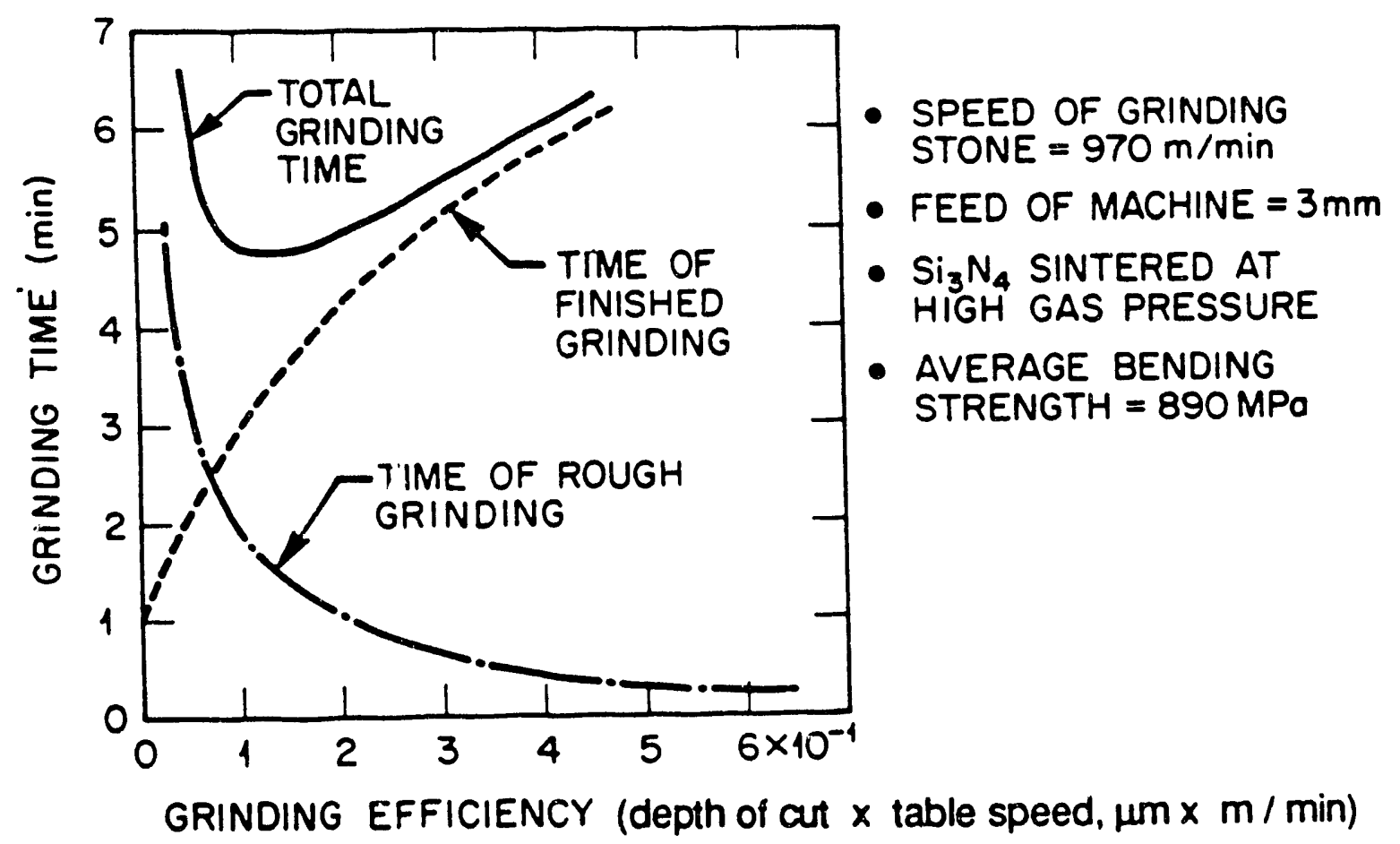

Figure 1. Relationship between grinding efficiency and grinding time for obtaining an average bending strength of $890 \mathrm{MPa}$ in silicon nitride [8].

\subsection{Mechanical Engineering Laboratory (MITI)}

The Mechanical Engineering Laboratory of the Ministry of International Trade and Industry (MITI) is one of the national research institutes in Tsukuba Science City, which is about $60 \mathrm{~km}$ northeast of Tokyo. Originally known as "Government Mechanical Laboratory", it was founded in 1937. Its purpose was original research for the rapid improvement of Japanese industry and reduction of its dependence on foreign technology. The research in this institute may be divided into three categories:

1. Large-scale Projects, which are performed by several laboratories (typical funding allotted for such a project may be up to 1000 million yen per year, but the amount allotted to each lab is not very high;

2. Special Researches for which 10 to 15 million yen per project may be allotted: and

3. Ordinary Researches for which funding varies from 1 to 2 million yen per project (the projects are mainly funded by the government.

MITI can have collaborative projects with the industries but not financial support only from industries. 
The laboratory has developed a high-performance creep-feed grinding of difficult-to-machine materials with a new type of wheels. These grinding wheels have a number of slots/segments, and in each slot cooling holes are drilled through the fluid chamber of the wheel working surface. The fluid supplied into the fluid chamber is forced out from the slots into the grinding zone by the centrifugal force performing effective cooling. Creep-feed grinding was performed with four types of ceramics. The details of their research can be obtained from two articles $[9,10]$. Two brief reports have been obtained: one on machining of ceramics [11] and the other on application of ceramics for machine tools [12]. Another paper entitled "A Simulation System for the Establishment of Grinding Operation Standards" was also obtained [13].

\subsection{Keio University}

Keio is a famous, private university founded in 1858. I. Inasaki is quite renowned in the field of grinding, especially grinding of ceramics. As current chairman of the Abrasive Technology Committee of the CIRP, he has been asked to deliver a keynote address on the future of abrasive technology at the CIRP annual meeting next year.

Professor Inasaki advocates speed-stroke grinding instead of creep-feed grinding. Speedstroke grinding is characterized by a high work speed and a small depth of cut. This method significantly reduces the grinding force. Five technical papers by Inasaki describe in detail the type of research being carried out on the area of grinding of ceramics [14-18]. One paper describes a new preparation method for producing resinoid-bonded CBN wheels [19]. The author has integrated the trueing and dressing processes for CBN grinding wheels with the use of a metal-bonded diamond wheel and steel wire brushes.

According to Inasaki, the research on ceramic machining started 7 or 8 years ago, and peaked 4 or 5 years ago. The research is almost complete in this area. Several sources of funding are available (e.g., government, university, cooperative research with industries, and various foundations). His annual budget was around 20 million yen (about $\$ 160,000$ ). He had 11 final year undergraduate students, 12 graduate students, and a research fellow. Generally there is no overhead charge, and salaries for the research personnel are paid from a separate fund. Very expensive instruments or machine tools are usually provided by industries.

\subsection{Institute of Vocational Training}

Kuniaki Unno, professor of the Institute of Vocational Training, was visited by Bandyopadhyay in September. A $1-\mathrm{kW}$ laser is used for machining small holes of $100-\mu \mathrm{m}$ diam in $\mathrm{Si}_{3} \mathrm{~N}_{4}$. This process is expected to find application in the semiconductor industry. Autofocusing is the objective of the research.

Ultrasonic Grinding of Ceramics for machining holes is the other area of research. Hole size of $10-\mathrm{mm}$ diam is machined by a metal-bonded diamond-grinding tool of 140-grit size and 100 concentration. The frequency of vibration is $20 \mathrm{kHz}$; maximum amplitude is $50 \mu \mathrm{m}$. The time required to machine a hole in a glass of $5-\mathrm{mm}$ thickness is $1 \mathrm{~s}$, while machining a hole in $\mathrm{Si}_{3} \mathrm{~N}_{4}$ of the same thickness is $5 \mathrm{~s}$. The material is removed by brittle fracture, and the surface finish depends on diameters of the abrasive and the fracture toughness of the ceramics. A sketch of the cutting tool is shown in Fig. 2. 


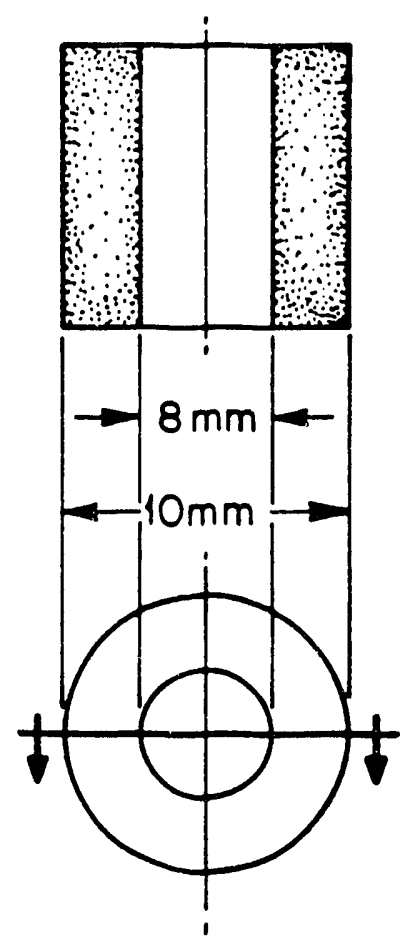

Fig. 2. Sketch of the tool used in ultrasonic grinding of ceramics. tool:

For efficient grinding of ceramics, the following requirements are essential from a machine

1. autobalancing system,

2. high rigidity, and

3. high damping.

The accuracy of spindle revolution should be about $0.2 \mu \mathrm{m}$, and the spindle rigidity is $20 \mathrm{kgf} / \mu \mathrm{m}$.

Hydrostatic bearings are accurate but low in rigidity (i.e., around $5 \mathrm{kgf} / \mu \mathrm{m}$ ). The hydrodynamic bearings are not good when the rpm is changed. Therefore, the concept of hybrid bearing has been developed where hydrostatic, and hydrodynamic effects, and also mechanical bearings can be used. The hybrid spindle design has been patented in Italy. Toyoda Machine Works. Ltd. has developed their own hybrid spindle bearing design. The automatic dressing of a metalbonded grinding wheel can be accomplished by the ELID system; therefore, automatic dressing of a vitrified bonded grinding wheel will be required in the future.

Research in the institute is carried out to determine the applied external pressure required to have ductile mode grinding. Figure 3 shows the relationship between the material removal rate and the external applied pressure on the wheel. $A 1_{2} \mathrm{O}_{3}$, and $\mathrm{Si}_{3} \mathrm{~N}_{4}$ have very narrow ductile mode zones; therefore, the grinding is performed in the brittle zone. However, $\mathrm{ZrO}_{2}$ has a wide ductile mode zone. 
In Fig. 3, the value of $P_{1}$ depends on the following factors:

1. fracture toughness,

2. hardness,

3. elastic modulus, and

4. condition of the wheel.

In a metal-bonded grinding wheel the pressure is high because elastic deformation is less; therefore, brittle mode grinding occurs. On the other hand, with a resin-bonded grinding wheel, ductile mode grinding may be easily obtained. With a fine mesh and a good dressing condition also, it is easy to get ductile mode grinding. With ductile mode grinding there will be minimum grinding defect.

Presently, the institute is involved in developing grindability data to establish a data base for grinding of ceramics. This institute belongs to the Ministry of Labor. Financial support for research is not available from the government.

\subsection{Japan Fine Ceramics Center, Nagoya}

About $30 \%$ of the employees at the Japan Fine Ceramics Center (JFCC) in Nagoya are from various companies. The organization structure and principal research topics are summarized in Figs. 4 and 5. Brochures obtained during the visit provided additional information $[20,21]$. They have excellent testing facilities such as $\mathrm{X}$-ray radiography for residual stress, ultrasonic microscope, high- temperature creep test laboratory, X-ray CATSCAN, tensile testing for life prediction of ceramics, thermal shock testing, etc. The tensile testing is performed with the test specimens machined from Kyocera material $\mathrm{Si}_{3} \mathrm{~N}_{4}$. According to JFCC reports, similar tests are being carried out at other laboratories abroad, even at ORNL. The objective is to develop standards for testing methods and a database. A CATSCAN photograph of a $\mathrm{Si}_{3} \mathrm{~N}_{4}$ specimen is shown in Fig. 6 . The system can identify a defect of minimum size of $20 \mu \mathrm{m}$, the diameter of a tungsten wire (natural crack). Detailed information was not available.

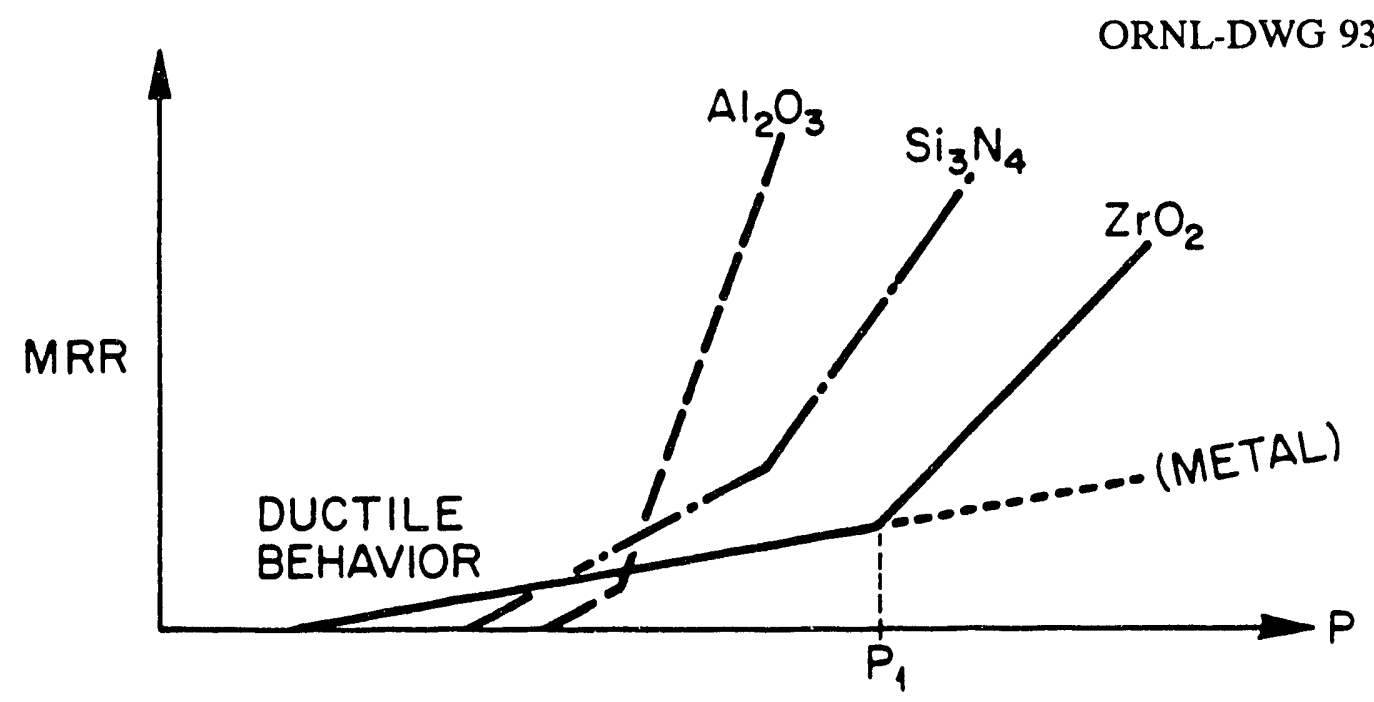

Figure 3. Relationship between material removal rate and applied pressure for various materials. 


\section{ORGANIZATION}

The organization is a flexible and efficient one, so that the staff may devote themselves to their work with zeal.

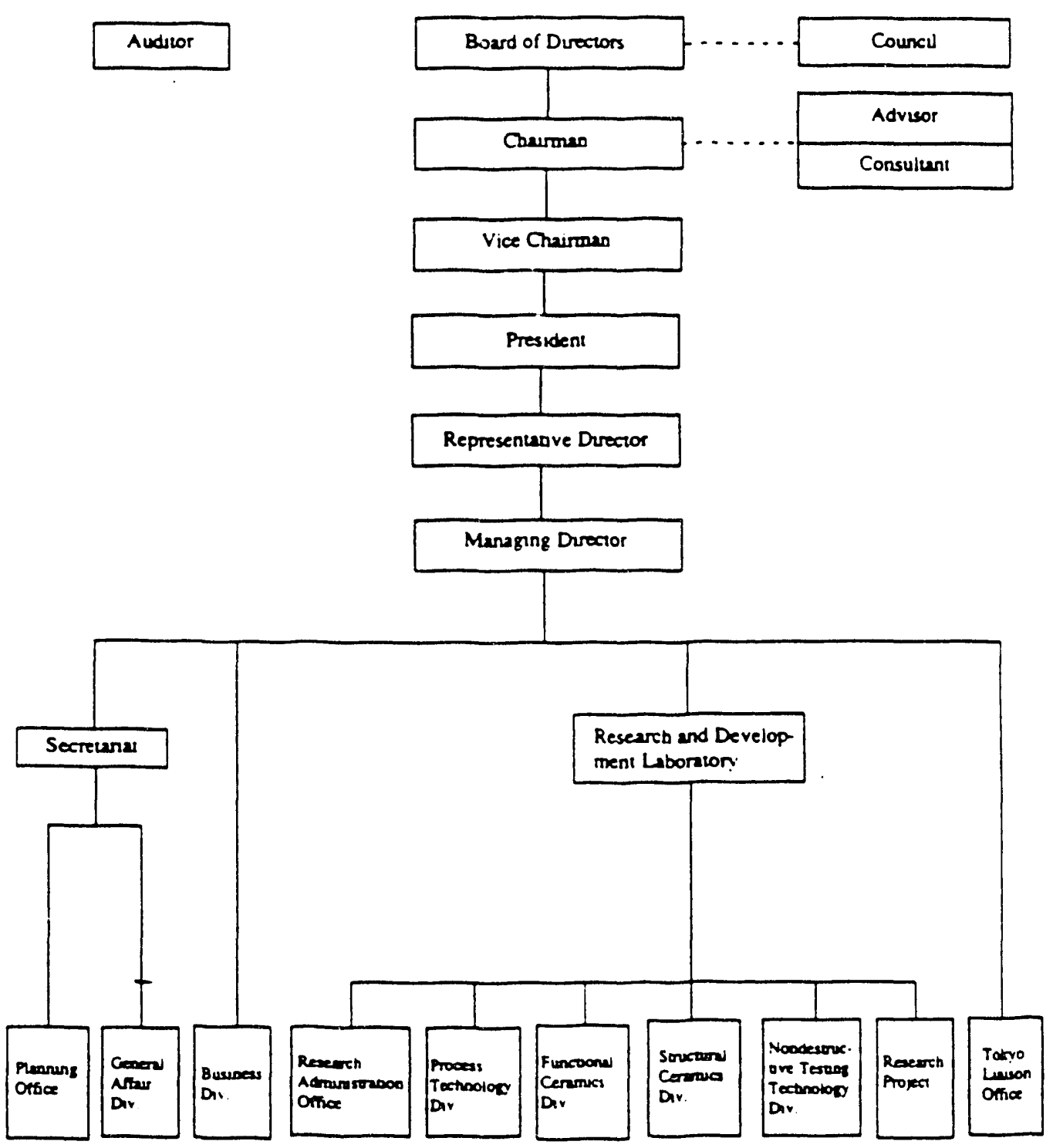

Figure 4. Organization of the Japan Fine Ceramics Center. 


\section{PRINCIPAL RESEARCH RESLLTS}

- Succeeded, for the first time in the world, in laking photographs continuously of the hightemperature structural ceramics at the moment of collapse by using the transmission electron microscope (TEM)

Functional Ceramics Div.

* Developed the ceramic thin film forming technology by using the molecular beam epitaxi (MBE) process, suggesting brighter prospect for the combination of high performance thin films such as artificial lartice, functionally gradient materials, etc.

Functional Ceramics Div.

- Clarified the strengthening mechanism of fine ceramic through analysis of the intergranular strucnure of the silicon nitride sintered body

Functional Ceramics Div.

* Synthesized of silver doped bismuth type superconducting bulk material having the world highest level IC by means of the JFCC's original floating zone melting technology

Functional Ceramics Div.

* Gave indications for engineering of new fine ceramics materials through quantitative analysis of fine ceramics manufacturing processes from adjustment of the material preparation to sintering

Process Technology Div.

* Developed and started distribution of a reference standard material. enabling transversal evaluation of the results of the test and research on the machining of fine ceramics Process Technology Div.

- Developed the SEVNB method and CVN method for revolutionary improvements in evaluation accuracy, through fracture toughness test

Structural Ceramics Div.

* Developed the friction and abrasion properties evaluation equipment for use under special environments (high temperature, high pressure, underwater)

Strucrural Ceramics Div.

* Established the flaw detecting technology in X-ray flaw detection methods and ultrasonic flaw detection methods, far surpassing coriventional detection capability

Nondestructive Testing Div.

Figure 5. Accomplishments of the Japan Fine Ceramics Center. 


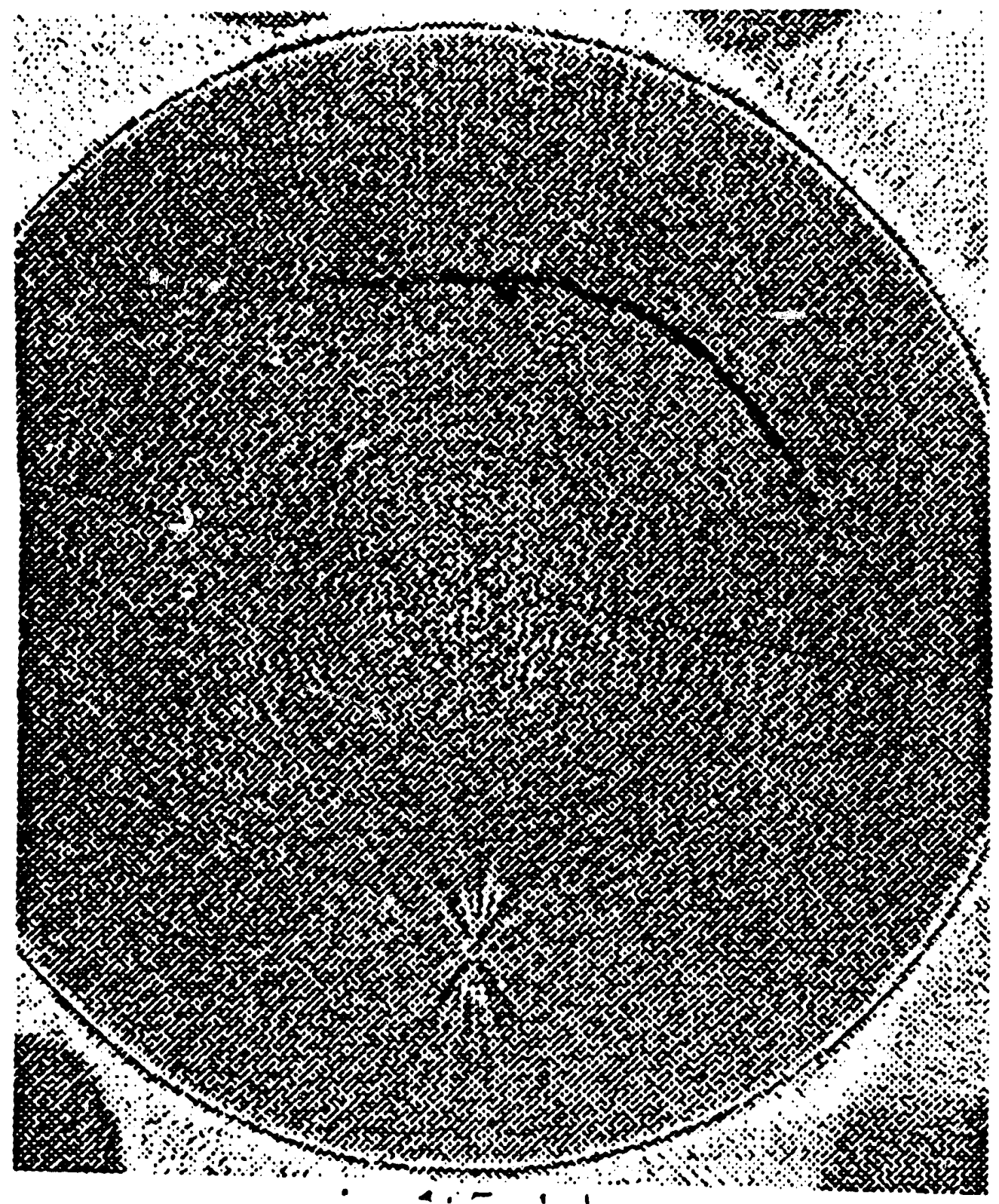

Figure 6. CATSCAN of a circular silicon nitride part showing internal flaws. 


\subsection{Government Industrial Research Institute, Nagoya}

Katsushi Kubo of the Government Industrial Research Institute, Nagoya (GIRIN) hosted Bandyopadhyay's visit. This institute is under the Ministry of International Trade and Industry (MITI) similar to that in Tsukuba. There are 180 people on the research staff: 100 of them are involved in ceramics. They have laboratories to investigate the mechanisms of sintering, a laboratory for preparation of specimens for mechanical testing of ceramics, and a creep-testing laboratory. Besides these laboratories, the institute has a carbon dioxide laser of $2-\mathrm{kW}$ power for machining ceramics. "Damageless machining" is the focus of that research. The institute found that thermal shock is a problem in laser machining. Preheating the workpices is proposed to minimize the thermal shock. Two articles on the effect of ceramics grinding on strength were obtained [22, 23]. A Ceramic Gas Turbine Project started 5 years ago (i.e., Moonlight Project) is expected to be completed in 1996.

\subsection{Aichi Industrial Research Institute}

Motohiro Suganuma, an expert on the scanning acoustic microscope (SAM), hosted a visit at the Aichi Industrial Research Institute. Hitachi manufactures one type of SAM. Knoop indentation was performed on $\mathrm{a} \mathrm{Si}_{3} \mathrm{~N}_{4}$ specimen with a force of $9.8 \mathrm{~N}$. The depth of the damage was found to be $17 \mu \mathrm{m}$. Figure 7 shows the relationship between the diameter of indentation damage and the bendino strength. Suganuma would like to use this concept to predict the bending strength indirectly by measurng the size of the damage by nondestructive evaluation.

\subsection{Chubu University}

Y. Namba hosted a visit to Chubu University. He has developed a glass ceramic spindle with zero thermal expansion. Two of his interesting papers on the subject were obtained $[24,25]$. He is working more with optical and electronic industries. He has obtained a surface finish of Rmax $=10$ A for optical glass.

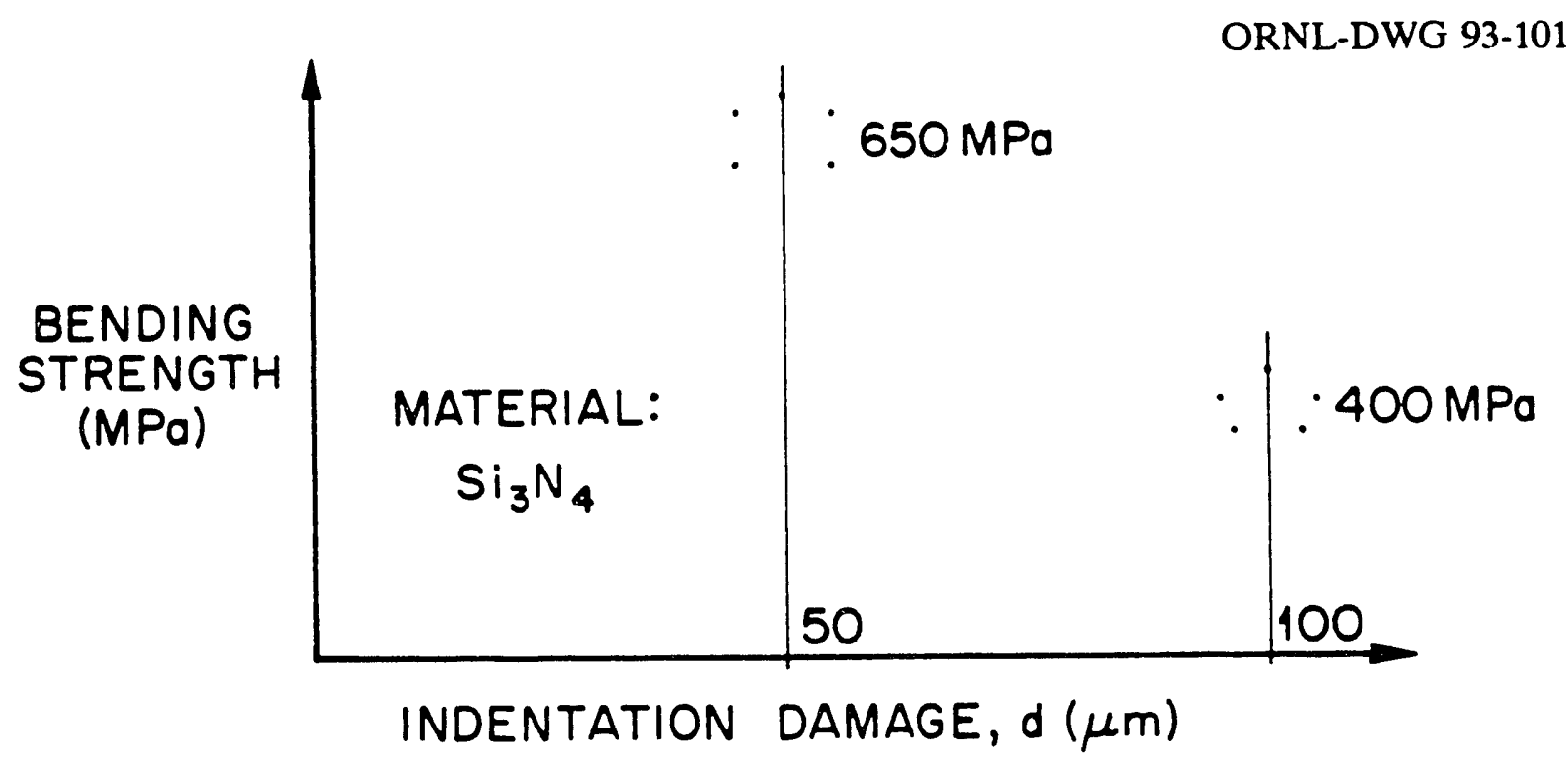

Figure 7. Relationship between indentation diameter and flexural strength for silicon nitride. 


\section{TRADE SHOWS}

\subsection{Nagoya Ceramics Fair}

The Ceramics Fair was held in Nagoya from March 11 through 15, 1992, at which time several important developments were shown:

Isuzu Ceramic Research Institute demonstrated ceramic parts to be used in ceramic engines. The company exhibited the car of the future, TERRAZA, in the 1991 Tokyo Motor show. This car will be marketed in 1995 . The company will be manufacturing the cams on the cam shaft from ceramics (e.g., $\mathrm{ZrO}_{2}$ plus $\mathrm{Al}_{2} \mathrm{O}_{3}$ ). The shaft itself will be made from steel. A company representative explained that the crack size after grinding is of the order of $30 \mu \mathrm{m}$, which is very difficult to detect with ultrasonic testing. However, Isuzu is removing these grinding cracks by lapping, which increases the strength of the part significantly (e.g., the strength of a $\mathrm{Si}_{3} \mathrm{~N}_{4}$ part may reach up to $1 \mathrm{GPa}$ using this technology). For parts like the exhaust manifold, the port liner, and the turbine scroll, the company is using low-thermal-conductivity material like $\mathrm{Al}_{2} \mathrm{TiO}_{5}$. The thermal conductivity of this material is about $1 / 10$ th that of $\mathrm{Si}_{3} \mathrm{~N}_{4}$.

Meiwa Industries manufactures ceramic coiled springs. Wicera engineering exhibited ceramic chains to be used in conveyers. The chain sprockets will be made from steel. The company also manufactures files from $\mathrm{ZrO}_{2}$. Kyocera also exhibited the following:

1. a ceramic ultraprecision straightness measuring machine,

2. a fine ceramic air bearing for measuring instruments, and

3. a ceramic air spindle unit (100 to $7200 \mathrm{rpm})$.

Fine, Sodick, and Toshiba exhibited ceramic surface plates of various sizes, high-precision ceramic V-blocks, and ceramic grinding centers. The "Magical V-Chuck" (vacuum chuck), produc 1 by FSK, will simplify work mounting during the grinding process. Hoechst CeramTech provided a brochure totally in English. Panosonic demonstrated artificial marbles for mounting their speakers.

A few companies demonstrated some diamond saw machines for slicing brittle materials. Other interesting machine tools displayed included the Stiper High Speed Ceramics Driller NDR 103 by Hitachi and CNC FM 505 Grinding Center by Brother. For the latter machine, coolant is provided from inside the spindle as well as from the outside. The amount of coolant supplied is $20 \mathrm{l} / \mathrm{min}$ from the outside, and $10 \mathrm{l} / \mathrm{min}$ at high pressure approximately $50 \mathrm{~kg} / \mathrm{cm}^{2}$ from the inside of the spindle. Before the grinding operation, automated dressing of the grinding wheel is accomplished. The grinding center can do core drilling, internal grinding, cylindrical grinding, etc. With the Super High Accuracy Grinding Center JV-5G by Toyoda, materials machined and their surface finishes were silicon carbide $(\mathrm{Rmax}=0.6 \mu \mathrm{m}), \mathrm{ZrO}_{2}(\mathrm{Rmax}=1.0 \mu \mathrm{m}), \mathrm{Al}_{2} \mathrm{O}_{3}(\mathrm{R} \max =0.8 \mu \mathrm{m})$, and $\mathrm{Si}_{3} \mathrm{~N}_{4}$ $(R \max =1.0 \mu \mathrm{m})$.

A CNC Cam Grinder GC-34N was exhibited by OKUMA. The same machine can be used for grinding ceramics and steels. A Diamond Pellet Grinding Machine was exhibited by SPEEDFAM Company. This unique machine performs plane grinding and lapping in one process. 


\subsection{Japan International Machine Tool Fair}

The Japan International Machine Tool Fair was held in Tokyo in November 1992. Osaka Diamond displayed diamond wheels for high-speed grinding and also new hybrid diamond wheels. The hybrid diamond wheel has both metal bonds and resin bonds. At present, the cost of a hybrid wheel is about $40 \%$ higher than that of a conventional resin-bunded diamond wheel for a diameter of $200 \mathrm{~mm}$ and a width of $25 \mathrm{~mm}$. Diamond and CBN tools are made by Mitsubishi materials.

A very interesting grinding machine was displayed by JUNKER MASCHINEN. The company claims a G-factor of 60,000 can be obtained. The grinding wheel width is only a few millimeters, and point contact is made during grinding. All these machines are provided with autobalancing of the wheels. Toyoda uses U.S. technology for autobalancing. The representative of Toyoda Machine Works, Ltd., Takao Miura, said that more information on autobalancing can be obtained from Grinder for Industries, Wixom, Michigan, [(313) 624-5755]. Nagase Integrex Company manufactures grinding machines vith an autobalancing system that combines a liquid-injection-type balancing unit with a microcomputer-based imbalance measuring unit. 


\subsection{OTHER COMMERCIAL PRODUCT DEVELOPMENTS}

\subsection{New, Patented Bonding Process for Manufacturing Grinding Wheels}

A technical bulletin on P.B.S., which is a patented bonding process to manufacture grinding tools, was obtained [26]. The process claims that the diamond particies are very strongly bonded into the wheel by fusing a hard, nickel-chromium alloy, instead of just being encapsulated, as in electroplated wheels. This type of grinding tool is available in various forms. They can be used for milling, drilling, etc. They can also be used for grinding of ceramics, but no technical data is available.

\section{$\underline{3.2 \text { Ceramic Ball Valves }}$}

Fujikin Incorporated manufactures fine ceramic ball valves. These valves have the following features: excellent corrosion resistance, superior erosion resistance, and low cavitation. Various sizes and types of ceramic valves are manufactured. The company has two branch offices in the United States: Englewood, New Jersey (201) 569-6360; and San Jose, California (408) 283-0270.

\subsection{Tools To Withstand Contact With Molten Aluminum}

Hitachi Metals, Inc., has developed new SiAlON ceramics parts to be used as jigs and tools that come into direct contact with molten aluminum. The properties of SiAlON developed by Hitachi Metals $\mathrm{HCN}-10$ are shown in Table 1.

Table 1.

PROPERTIES OF HITACHI HCN-10

\begin{tabular}{|c|c|c|}
\hline Property & Value & Units \\
\hline Density & 3.26 & $\mathrm{~g} / \mathrm{cm}^{3}$ \\
\hline 3-point bend strength & $90.0(883)$ & $\mathrm{kgf} / \mathrm{mm}^{2}(\mathrm{MPa})$ \\
\hline Weibull coefficient & 11. & $\ldots$. \\
\hline Fracture toughness $\left(\mathrm{K}_{\mathrm{ic}}\right)$ & 6.0 & $\mathrm{MPa} \mathrm{m}^{\wedge} .5$ \\
\hline Thermal expansion coeff. & 3.0 & $\times 10^{-6} / \operatorname{deg} C$ \\
\hline Thermal conductivity & 0.04 & $\mathrm{cal} / \mathrm{cm}$-s-deg C \\
\hline Young's modulus & 294.3 & $\mathrm{GPa}$ \\
\hline
\end{tabular}

Research is being conducted by Hitachi for the development of automotive parts from SiAlON. 


\subsection{Sintobrator, Lt 1 ., Manufacturer of ELID Systems}

Sintobrator, Ltd., in Toyokawa manufacturers and markets the ELID grinding system. At present, 50 companies in Japan are using this system, and another 50 companies have started testing the system. For the efficient operation of ELID grinding, the gap between the electrode and the grinding wheel is critical. The company has recently developed ELID-OPTIMA for automatic adjustment of the gap. No detailed technical information is available at this moment. The ELID grinding system has been successfully applied to the following grinding operations: rotary surface grinder, machining center, surface grinder, in-feed grinder, lap-grinder, and internal grinder. This company also markets the new advanced grinding wheel known as Mighty Cerax. This is a cast iron fiber bonded diamond grinding wheel. These grinding wheels are manufactured by the sintering process. First, the wheel hardness is monitored and then the tensile strength of the specimen is measured. The tensile strength test specimen is produced simultaneously during the sintering process. 


\section{REFERENCES}

1. T. Nakagawa, K. Suzuki, and T. Uematsu, "Three Dimensional Creep Feed Grinding of Ceramics by Machining Center," pp. 1-7 in Machining of Ceramic Materials and Components, PED, Vol. 17, ASME, 1985.

2. T. Uematsu, K. Suzuki, T. Yanase, and T. Nakagawa, "A New Complex Grinding Method for Ceramic Materials Combined with Ultrasonic Vibration and Electrodischarge Machining," pp. 135-140 in Intersociety Symposium on Machining of Advanced Ceramic Materials and Components, ASME, 1988.

3. H. Ohmori and T. Nakagawa, "Mirror Surface Grinding of Silicon Wafers with Electrolytic InProcess Dressing," Annals of the CIRP 39(1) 329 (1990).

4. H. Ohmori and T. Nakagawa, "Electrolytic In-Process Dressing (ELID) for Mirror Surface Grinding," unpublished data.

5. H. Ohmori, I. Takahashi, and T. Nakagawa, "Mirror Surface grinding by Metal Bonded Superabrasive Wheel with Electrolytic In-Process Dressing," presented at the "Progress in Precision Engineering Conference," Braunschweig, Germany, May 1991.

6. Y. Matsuo, T. Nishimura, K. Yasuda, K Jinbo, and S. Kimura, "Improvement of Structural Reliability of Sintered Alumina by New Powder Forming Method," pp. 151-57 in Mat'l. Res. Soc., Intern'l Meeting on Adv. Mat'ls., Vol. 5, 1989.

7. Y. Matsuo, T. Ogasawara, S. Kimura, S. Sato, and E. Yasuda, "The Effects of Annealing on Surface Machining Damage of Alumina Ceramics," J. of Cer. Soc. of Japan, int'l. edition, 99(5), 371 (1991).

8. H. Kawamura, "Study of Grinding Process and Strength for Ceramic Heat Insulated Engine," unpublished data.

9. T. Suto, T. Waida, H. Noguchi, and H. Inoue, "High Performance Creep Feed Grinding of Difficult-to-Machine Materials with New-Type Wheels," Bull. Jap. Soc. of Prec. Engr., 24(1), 39 (1990).

10. T. Suto, T. Waida, H. Noguchi, and M. Razaei, "Creep Feed Grinding of Ceramic-Matrix Composites with a Segmented and Perforated Wheel," Bull. Jap. Soc. of Prec. Engr., 24(3), 227 (1990).

11. Production Engineering Department, Machining of Ceramics - High Performance Ceramics (Project of Basic Technology for Future Industries), AIST-MITI, Tsukuba Science City (1982).

12. Production Engineering Department, Application of Ceramics for Machine Tool, AIST-MITI, Tsukuba Science City (1984). 
13. T. Suto, E-S. Lee, and J-K. Lee, "A Simulation System for the Establishment of Grinding Operation Standards," pp. 380-87 in Proc. 16th North Amer. Manuf. Res. Conf., SME, Dearborn, Mich., 1988.

14. I. Inasaki, "High Efficiency Grinding of Advanced Ceramics," Ann. of the CIRP, 35(1), 211 (1986).

15. I. Inasaki, "Grinding of Hard and Brittle Materials," Ann. of the CIRP, 36(2), 463 (1987).

16. I. Inasaki, "Speed-Stroke Grinding of Advanced Ceramics," Ann. of the CIRP, 37(1), 299 (1988).

17. C. Chen, S. Sakai, and I. Inasaki, "Lapping of Advanced Ceramics," Mater. and Manuf. Processes, 6(2), 211 (1991).

18. C. Chen, Y. Jung, and I. Inasaki, "Surface, Cylindrical, and Internal Grinding of Advanced Ceramics," p. 201-11 in Grinding Fundamentals and Applications, ed. Malkin and Kovach, PED, Vol. 39, ASME, 1989.

19. I. Inasaki, "A New Preparation Method for Resinoid-Bonded CBN Wheels," Ann. of the CIRP, 39(1), 317 (1990).

20. Japan Fine Ceramics Center Today, December 1991.

21. Let's Together, Japan Fine Ceramics Center, ND.

22. W. Kanematsu, S. Sakai, Y. Yamauchi, S. Ito, and K. Kubo, "Effects of Grinding on the Dynamic Fatigue Behavior and Strength Degradation of Hot Pressed Silicon Nitride Ceramics at Room Temperature," Nippon Seramikkasu Kyokai Gakujutsu Ronbunshi, 98(11), 1287 (1990).

23. W. Kanematsu, Y. Yamaguchi, T. Ohji, S. Ito, and K. Kubo, "A Model for the Effect of Grinding on the Strength Degradation of Ceramics," Theor. and Appl. Mech., submitted for publication.

24. Y. Namba, R. Wada, K. Unno, and A. Tsuboi, "Ultra-Precision Surface Grinder Having a GlassCeramic Spindle of Zero-Thermal Expansion," Ann. of the CIRP, 38(1), 331 (1989).

25. Y. Namba, Y. Yamada, A. Tsuboi, K. Unno, and H. Nakao, "Surface Structure of Mn-Zn Ferrite Single Crystals Ground by an Ultraprecision Surface Grinder with Various Diamond Wheels," Ann. of the CIRP, 41(1), 347 (1992).

26. "P. B. S.(R) vs. Electroplating," tech. bulletin, ND. 


\section{KEY RESEARCHERS IN CERAMICS MACHINING IN JAPAN}

1. Dr. Hitoshi Ohmori

Head o? the ELID grinding project

Institute of Physical and Chemical Research (RIKEN)

1-17-13 Kaga Itabashi-ward

Tokyo 173, JAPAN

FAX \# 81-3-3579-5940

2. Dr. Tetsuo Suto, Director

Machining Technology Division

Mechanical Engineering Laboratory

1-2 Namiki, Tsukuba-shi

Ibaraki, 305, JAPAN

FAX \# 81-298-58-7201

3. Dr. Ichiro Inasaki, Professor

Keio University

Faculty of Science and Technology

3-14-1, Hiyoshi Kohoku-ku

Yokohama-shi, JAPAN

FAX \# 81-45-563-2472

4. Dr. Kuniaki Unno, Professor

The Institute of Vocational Training

1960, Aihara, Sagamihara

Kanagawa 229, JAPAN

FAX \# 81-427-63-9132

5. Mr. Shogo Suzuki, Manager

Advanced Material Laboratory

ISUZU CERAMICS RESEARCH INSTITUTE CO., LTD.

8 Tsuchidana, Fujisawa

Kanagawa-ken, 252 JAPAN

FAX \#81-466-45-2728

6. Mr. Hiroshi Kawamoto, Manager

Structural Ceramics Division I

Research and Development Laboratory

Japan Fine Ceramics Center (JFCC)

2-4-1 Mutsuno, Atsuta-ku

Nagoya, 456 JAPAN

FAX \# 81-52-871-3599 
7. Dr. Katsushi Kubo, Manager

Department of Mechanical Engineering

MITI Government Industrial Research Institute

Nagoya

1-1 Hirate-cho, Kita-ku

Nagoya, JAPAN

FAX \# 81-52-916-2802.

8. Dr. Motohiro Suganuma

Industrial Research Institute

Aichi Prefectural Government

Nishishinwari, Hitotsugi-cho

Kariya 448, JAPAN

FAX \# 81-566-22-8033

9. Dr. Yoshiharu Namba, Professor

Department of Mechanical Engineering

CHUBU UNIVERSITY

1200 Matsumoto-cho, Kasugai

Aichi 487, JAPAN

Tel: 81-568-51-1111

10. Dr. Yohtaro J. Matsuo

Department of Inorganic Materials

Faculty of Engineering

Tokyo Institute of Technology

2-12-1 Ookayama, Meguro-ku

Tokyo 152, JAPAN

FAX \# 81-3-729-0393

11. Mr. Takao Miura

Assistant Manager, Overseas Sales Dept.

Toyoda Machine Works Ltd.

Post Code 448

1-1 Asahimachi, Kariya

Aichi, JAPAN

FAX \# 81-566-25-5472

12. Mr. Tatsuro Hirokawa

Trading Section, International Dept.

Osaka Diamond Industrial Co. Ltd.

2-80, Ohtori, Kitamachi

Sakai City, Osaka-Pref. 593 JAPAN

FAX \# 81-722-62-7494 
13. Mr. Moriyasu Izawa

R \& D Department

Sintobrator Ltd.

Toyoda Building, 4-chome, Mei-eki

Nakamura-ku, Nagoya 450, JAPAN

FAX \# 81-5338-4-2725

14. Mr. Toshio Okitsu

Senior Engineer

Reserarch Development Center

Wakamatsu Works, Hitachi Metals Ltd.

1-9-1, Kitahama, Wakamatsu-ku

Kitakyushu-shi 808, JAPAN

FAX \# 81-93-761-5362

15. Mr. Masaru Amano

Overseas Trade Dept.

LUXO Co. Ltd.

131, Naksuna-cho, Tenpaku-ku,

Nagoya 468 JAPAN

FAX \# 81-52-834-2743

16. Mr. Yukiyasu Nagase

Vice President, Nagase Integrex Co., Ltd.

Atobe Mugegawa-cho, Mugi-gun

Gifu-Ken, JAPAN

FAX \# 81-575-46-2325

17. Dr. Jun-Ichiro Takagi

Department of Mechanical Engineering

Yokahama National University

156 Tokiwadai, Hodogaya-ku

Yokahama, 240 JAPAN

FAX \# 81-45-331-6593 


\title{
INTERNAL DISTRIBUTION
}

\author{
1-2. Laboratory Records Department \\ 3. Laboratory Records, ORNL-RC \\ 4. ORNL Patent Section \\ 5-7. M\&C Records Office \\ 8. P. J. Blau \\ 9. G. M. Caton \\ 10. W. H. Elliot, Jr. \\ 11. H. L. Gerth \\ 12-16. D. R. Johnson
}

\author{
17. W. K. Kahl \\ 18. E. L. Long, Jr. \\ 19. A. J. Moorehead \\ 20. A. E. Pasto \\ 21. V. J. Tennery \\ 22. S. G. Winslow \\ 23. J. M. Wyrick \\ 24. C. S. Yust
}

\section{EXTERNAL DISTRIBUTION}

25. Meryl D. W. Adler, Corning RD\&E Div., SP PR 01 C21 PRC, Corning, iJY 14831

26. Kenneth A. Anderson, Jr., WR Grace/Diamonite, 453 W. McConkey Street, Shreve, OH 44676

27. Patrick R. Annese, BMS, 334 Washington Street, Somerville, MA 02143

28. Harold Arneson, Frof. Instrum. Co., 4601 Highway 7, Minneapolis, MN 55416

29. Peter C. Balson, Diacraft, Inc., 9033 General Drive, Plymouth, MI 48170

30-34. B. P. Bandyopadhyay, Eniversity of North Dakota, Box 8214 Univ. Sta., Grand Forks, ND 58202

35. Chander P. Bhateja, Contemporary Technologies, 14 Pinnacle Road, Farmington, CT 06032

36. Thomas Bifano, Boston University, Aerospace and Mechanical Engineering, Boston, MA 02215

37. James R. Blackmore, Norton/TRW Ceramics, 7A-4 Raymond Avenue, Salem, NH 03079

38. Joseph F. Braza, Torrington/Advanced Technology, 59 Field Street, Torrington, CT 06790 
39. Charles B. Burk, CERBEC, 10 Airport Park Road, East Granby, CT 06026

40. Bcrnard J. Busovne, AlliedSignal, Inc., 2525 W. 190th Street, Torrance, CA $90509-2960$

41. Alan C. Carius, GE Superabrasives, 6325 Huntley Road, Worthington, OH 43085

42. J. Mark Chenoweth, Coors Technical Ceramics, 1100 Commerce Park Drive, Oak Ridge, TN 37830

43. William J. Chmura, Torrington Company, 59 Field Street, Torrington, CT 06790

44. Keith P. Costello, Chand Kare Technical Ceramics, 2 Coppage Drive, Worcester, MA 01603

45. Henrik Lyshoj Dam, Danish Technical Institute, P.O. Box 141-DK 2630, Taastrup - DENMARK

46. Tom L. Davidson, Diacraft, Inc., P.O. Box 1135, Dickson, TN 37055

47. Frank G. Davis, Allied-Signal Aerospace Company, 1001 Pennsylvania Avenue, N.W., Washington, DC 20004

48. David Dudley, Diacraft, Inc., P.O. Box 1135, Dickson, TN 37055

49. Tommy Ellenburg, Hwyck Formex, P.O. Box 1030, Greenville, TN 37744

50. William A. Ellingson, Argonne National Laboratory, 6700 S. Cass Avenue, Argonne, IL 60439

51. David T. Ellis, Machined Ceramics, 629 N. Graham Street, Bowling Green, KY 42101

52. George O. Ellis, Machined Ceramics, 629 N. Graham Street, Bowling Green, KY 42101

53. Ronald K. Ellswood, Detroit Diesel Corporation, 13400 Outer Drive West, Detroit, MI 48239-4001

54. Christopher Evans, NIST, Metrology A-107, Gaithersburg, MD 20899

55. Michael E. Finn, I A M S, 111 Edison Drive, Cincinnati, OH 45069

56. Robert Frech, Eonic, Inc., 464 E. Hollywood, Detroit, MI 48203-2099

57. J. Randall Gilmore, ExtrudeHone, 8075 Pennsylvania Avenue, Irwin, PA 15642 
58. Leigh C. Girard, Gaumeyer \& Livingston, 336 Straight Avenue S.W., Grand Rapids, MI 49442

59. Ed Gizonski, Eonic, Inc., 464 E. Hollywood, Detroit, MI 48203-2099

60. Brian H. Gold, STC Corp., P.O. Box 1028, St. Albans, VT 05478

61. Allan E. Goldman, CGM Co., 907 W. Outer Drive, Oak Ridge, TN 37830

62. Frank Gorman, Astro Met Inc., 9974 Springfield Pk., Cincinnati, OH 45215

63. H. Gupta, U. of CT-Grind Res Ct, 191 Auditorium Road, Storrs, CT 06269-3237

64. Robert A. Haines, INSACO, Inc., P.O. Box 9006, Quakertown, PA 18951-9006́

65. Nabil S. Hakim, Detroit Diesel Corporation, 13400 Outer Drive West, Detroit, MI 48239-4001

66. Keith Hale, Deco-Grand, Inc., 4850 Coolidge Hwy., Royal Oak, MI 48073-1023

67. Marcel R. Hanard, II., Caterpillar Technical Center, P.O. Box 1875, Peoria, IL 61656-1875

68. Sazzadul Haque, Cummins Engine Co., 1900 McKinley Avenue (50183), Columbus, IN $47202-3005$

69. Alan M. Hart, Dow Chemical Company, 1776 Building, Midland, MI 48674

70. Ray Hartzell, Defiance Precision Products, P.O. Box 428, Defiance, OH 43512

71. Michael H. Haselkorn, Caterpillar Technical Center, P.O. Box 1875, Peoria, IL . 61656-1875

72. Said Jahanmir, NIST, Bldg. 220, Rm. A-215, Gaithersburg, MD 20899

73. Per Quist Jensen, Danish Technical Institute, P.O. Box 141-DK 2630, Taastrup DENMARK

74. Ralph Kelly, Cincinnati Milacron, P.O. Box 9013, Cincinnati, OH 45209

75. Michael P. King, Carborundum Company, P.O. Box 337, Niagara Falls, NY 14302

76. Joseph Kovach, Eaton Corporation, 32500 Chardon Road, Willoughby Hills, $\mathrm{OH} 44094$

77. K. V. Kumar, GE Superabrasives, 6325 Huntley Road, Worthington, OH 43085

78. Roberl H. Licht, Norton Company, Goddard Road, Northboro, MA 01532-1545 
79. Edward Lilley, Norton Company, Northboro Research Center, Northboro, MA 01532

80. Frederick W. Lindblad, Ultra Diamond Co., 102 S. 13th Avenue, St. Charles, IL 60174

81. Jack F. Lininger, DU-CO Ceramics Co., 155 S. Rebecca Street, Saxonburg, PA 16056

82. Jay Lunzer, Lunzer, Inc. - Applied Technology, 330 W. 42nd Street, New York, NY 10036

83. William A. Mack, Carborundum Company, P.O. Box 337, Niagara Falls, NY 14302

84. Steyen Malkin, University of Massachusetts, Department of Mechanical Engineering, Amherst, MA 01003

85. Richard Marshall, Diacraft, Inc., 9033 General Drive, Plymouth, MI 48170

86. John E. Mayer, Jr., Texas A\&M University, 117G Thompson Hall, College Station, TX $77843-3367$

87. Bradley J. Mil!er, Pakco, 55 Hillview Avenue, Latrobe, PA 15650

88. Sanjay Mishı ג, Chand Kare Technical Ceramics, 2 Coppage Drive, Worcester, MA 01603

89. Clay Morgan, Kyocera Industrial Ceramics Company, 5713 E. Fourth Plain Blvd., Vancouver, WA 98661

90. J. Joseph Notardonat\%, NASA-Lewis Research Center, 21000 Brookpark Road, Cleveland, $\mathrm{OH} 44135$

91. Thumas J. Parsons, Dow Chemical Company, 1616 Building, Midland, MI 48667

92. Feter L. Perdue, Detroit Diesel Corpuration, 3400 Outer Drive West, Detroit, MI 48239-4001

93. William W. Pflager, Litton Ind. Automat., 20 E. 6th Street, Waynesboro, PA 17268

94. Joseph Picone, Norton Company, 1 New Bond Street, Worcester, MA 01606

95. Vimal K. Pujari, Norton Company, Goddard Road, Northboro, MA 01532-1545

96. Mary C. Pung, Diacraft, Inc., 9033 General Drive, Plymouth, MI 48170

97. Robert C. Pung, Diacraft, Inc., 9033 General Drive, Plymouth, MI 48170

98. Richard G. Rateick, Jr., Allied-Signal, 717 N. Bendix Drive, South Bend, IN 46620 
99. Stephen G. Reder, Torrington Company, 59 Field Street, Torrington, CT $06790-4942$

100. Patrick Redington, Norton Cumpany, 1 New Bond Street, Bldg. 410, Worcester, MA 01606

101. Frank D. Reed, INSACO, Inc., P.O. Box 9006, Quakertown, PA 18951-9006

102. Ed Ryan, Defiance Precision Products, P.O. Box 428, Defiance, OH 43512

103. Steven L. Sanner, Prof. Instrum. Co., 4607 Highway 7, Minneapolis, MN 55416

104. Robert B. Schulz, U.S. Department of Energy, CE-34 Forrestal Building, Washington, DC 20585

105. Steve Schwegler, Radiac Abrasives, Inc., 742A Bates Road, Lebanon, TN 37087

106. Jack D. Sibold, Coors Ceramics Company, 4545 McIntyre Street, Golden, CO 80403

107. P. C. Smith, WESGO, 477 Harbor Blvd., Belmont, CA 94002

108. Philippe D. St-Pierre, COMTEK, 235 Medick Way, Worthington, OH 43085

109. Irving F. Stowers, LLNL, P.O. Box 808, L-791, Livermore, CA 94550

110. Robert Straub, Diesel Technology, 2300 Burlingame Avenue, S.W., Wyoming, MI 49509-0919

11. Dan Strong, Corning RD\&E Div., SP PR 01 C34 PRC, Painted Post, NY 14870

112. K. Subramanian, Norton Company, 1 New Bond Street, Worcester, MA 01615-0008

113. Dennis M. Tracey, St. Gobain/Norton, Goddard Road, Northboro, MA 01532-1545

114. Carl F. Van Conant, Boride Products, Inc., 2879 Aero Park Drive, Traverse City, MI 49684

115. Ron Walecki, AlliedSignal, Inc., 2525 W. 190th Street, Torrance, CA 90509-2960

116. Robert D. West, Therm Advanced Ceramics, P.O. Box 220, Ithaca, NY 14851

117. John Ziegler, Vesuvius, 1508 Second Street, New Brighton, PA 15066

118. Office of Assistant Manager ior Energy Research and Development, U.S. Department of Energy, Oak Riage Operations Office, P.O. Box 2001, Oak Ridge, TN 378.31

119-120. U.S. Department of Energy, Office of Scientific and Technical Information, P.O. Box 62, Oak Ridge, TN 37831 

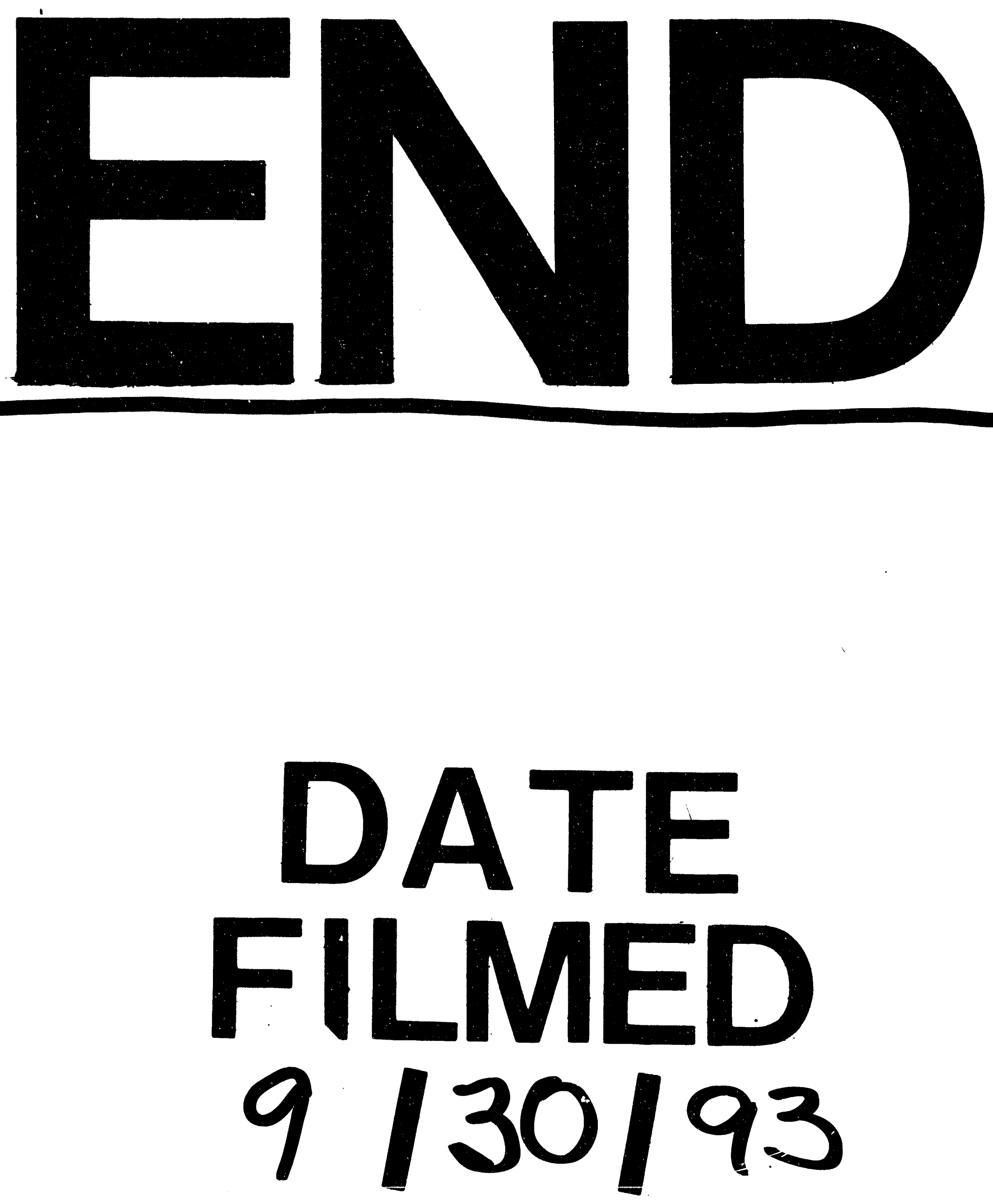

I 
